\title{
Ziek van de ramp of van het nieuws óver de ramp?
}

Peter Vasterman \& Joris IJzermans

'Things only go wrong when the nature of an outbreak is not recognized, and a fruitless and expensive search for toxins, fumes and gases begins. Anxiety, far from being reduced, increases. It is only then that long-term psychological problems may develop.'

Simon Wessely

\section{Na de Bijlmercrash}

Bij het neerstorten van de $\mathrm{El} \mathrm{Al}$ vracht Boeing 747 op twee flatgebouwen in de Bijlmermeer op zondagavond vier oktober 1992 vallen inclusief de bemanning 43 doden en een relatief klein aantal gewonden. Enkele honderden mensen krijgen in de maanden daarna enige vorm van psychologische begeleiding om het trauma van de crash te helpen verwerken. De oorzaak van de ramp is vrij snel duidelijk: metaalmoeheid in de motorophanging leidt tot het afbreken van beide motoren op de rechtervleugel. Daarmee lijkt de zaak afgedaan, maar net als bij veel andere rampen biedt ook de Bijlmerramp een vruchtbare voedingsbodem voor speculaties, geruchten en complottheorieën. Meteen al na de crash zijn er geruchten over plunderingen op de rampplek en veel grotere aantallen slachtoffers (illegalen), van wie geen spoor teruggevonden kon worden door de intense hitte. In de jaren daarna komen er steeds meer 'mysteries' bij, waarin de lading en de mogelijke betrokkenheid van geheime diensten ('mannen in witte pakken') een centrale rol spelen. Een bewoner ontdekt op de rampplek restanten van de vrachtbrieven waarin sprake is van 'military ordince equipment', hetgeen in tegenspraak is met de officiële lezing over computers, bloemen en parfum. Nader onderzoek toont aan dat het vliegtuig inderdaad 'military equipment' vervoerde, maar specifieke informatie over de inhoud lijkt op dat moment niet meer te achterhalen. Een jaar later onthult Trouw dat het vliegtuig gevaarlijke, giftige stoffen vervoerde. 'Milieudeskundigen om- 
schrijven het ramptoestel als "een vliegende verf- of chemiefabriek".' Op dat moment komen ook de eerste meldingen van Bijlmerbewoners en hulpverleners met gezondheidsklachten. 'Door sommigen wordt een relatie gelegd met de Bijlmerramp. Wanneer in oktober 1993 de Stichting Visie (een afsplitsing van LAKA, het Landelijk Anti-Kernenergie Archief) openbaar maakt dat in het verongelukte vliegtuig verarmd uranium als balansgewicht was verwerkt, neemt de ongerustheid toe." Verschillende onderzoeksinstanties zijn van mening dat de gezondheidsklachten niet veroorzaakt kunnen zijn door gevaarlijke stoffen in het vliegtuig. Maar de precieze lading is nog steeds niet bekend en van de 385 kilo verarmd uranium is dan slechts 112 kilo teruggevonden. Na onderzoek blijkt 48 kilo verarmd uranium tussen de brokstukken van het vliegtuig te liggen. Die ontdekking leidt later tot een nieuwe groep verontrusten, namelijk de mensen die de restanten hebben verzameld en degenen die in de hangar hebben gewerkt waar de wrakstukken zijn opgeslagen. In de zomer van 1994 wordt bekend dat de rest van het verarmd uranium terecht is gekomen op een stortplaats, alwaar medewerkers meteen een onderzoek eisen. In het najaar van 1997 onthult Trouw (17 september 1997) dat verarmd uranium bij veel lagere temperaturen kan oxideren dan de overheid tot dan toe heeft gemeld. De toenemende verontrusting is voor de overheid aanleiding een gezondheidsonderzoek door het AMC (Academisch Medisch Centrum, Amsterdam) in te stellen, bestaande uit interviews met huisartsen, analyses van medische dossiers en het instellen van een telefonisch meldpunt voor mensen met klachten. Bovendien komt er een nieuw onderzoek naar de lading, uit te voeren door de commissie Hoekstra, die in de zomer van 1998 zal rapporteren. In maart 1998 ontstaat opnieuw opschudding wanneer de Stichting Visie meldt dat er verhoogde niveau's van uranium zijn ontdekt in de faeces van enkele hulpverleners. Meteen komt er veel kritiek op dit onderzoek, maar de onthulling dat een aantal medewerkers uit de hangar ook gezondheidsklachten meldt, zorgt weer voor nieuwe onrust. In de maanden daarna neemt de onzekerheid alleen maar verder toe: de commissie Hoekstra kan van 34 ton lading de inhoud niet achterhalen, en onderzoeksinstituut ECN (Energie-onderzoekscentrum Nederland) blijkt na nieuw onderzoek niet uit te sluiten dat er misschien toch verarmd uranium is verstoven tijdens de crash. Als klap op de vuurpijl onthult NRC Handelsblad dat het vliegtuig grondstoffen voor het zenuwgas Sarin aan boord had. Op zichzelf niet gevaarlijk, oordelen deskundigen, maar de verontrusting neemt weer verder toe. Kort daarna, op 30 september, besluit de Tweede Kamer een parlementaire enquête te houden. Trouw komt in het kielzog van de NRConthulling met het nieuws dat de lading van de $\mathrm{El} \mathrm{Al} \mathrm{Boeing} \mathrm{nucleair} \mathrm{moet}$ zijn geweest ('Lading El Al-Boeing nucleair', I oktober 1998) op basis van onderzoek naar monsters Bijlmergrond en stof uit hangar 8. Inmiddels 
hebben AMC-onderzoekers melding gemaakt van enkele gevallen van autoimmuunziekte.

De parlementaire enquête in het voorjaar van 1999 trekt buitengewoon veel media-aandacht. De ontdekking van een geluidsband waarop verkeersleiders met $\mathrm{El} \mathrm{Al}$ afspreken om informatie over lading ('giffen, gassen, explosieven') 'onder de pet te houden,' leidt tot nationale verontwaardiging. Deze grote 'doorbraak' blijkt bij nader inzien op een misverstand te berusten en na alle opwinding en verontwaardiging komt het eindrapport, dat op 22 april 1999 verschijnt, als een anticlimax. Het rapport Beladen vlucht rekent af met alle complottheorieën, geruchten en speculaties rond de Bijlmerramp. Geen giftige lading, geen wapens, geen explosieven, geen betrokkenheid van geheime diensten en geen extra gezondheidsrisico's door het verarmd uranium. De commissie spreekt wel van een directe relatie tussen de ramp en gezondheidsklachten, die zijn toegenomen door traagheid en onderschatting bij de overheid, maar dan gaat het voornamelijk om pTssgerelateerde problemen. De enquêtecommissie sluit echter niet uit dat 'individuen' chronische gezondheidsklachten hebben opgelopen door blootstelling aan giftige stoffen. Niettemin melden zich ruim zesduizend mensen aan voor het individueel medisch onderzoek dat op advies van het eindrapport wordt ingesteld. Net als bij eerder onderzoek kan er geen ziektebeeld worden vastgesteld, laat staan een oorzaak als verarmd uranium, gifgassen of dioxine. Bij driekwart van de onderzoeksgroep wordt geen enkele aanwijzing gevonden voor een link met de ramp, de rest wordt doorverwezen naar speciale nazorg in verband met psychische klachten.

In al die jaren van onzekerheid en verontrusting raken steeds meer 'Bijlmerzieken' ervan overtuigd dat hun 'ziekte' is veroorzaakt door de blootstelling aan giftige stoffen direct na de ramp. Aanvankelijk gaat het nog om enkele tientallen, maar later om honderden, zelfs duizenden mensen die zeggen ziek te zijn geworden van de ramp, en die psychische verklaringen als posttraumatische stressstoornis (PTSS) verontwaardigd van de hand wijzen. De overheid slaagt er in al die jaren niet in om cruciale vragen over de lading en het verarmd uranium bevredigend te beantwoorden. Er is weinig samenhang in de (elkaar soms tegensprekende) reacties van de verschillende overheden, die telkens overvallen worden door onverwachte incidenten en opzienbarende onthullingen. Dat trage en onsamenhangende optreden ${ }^{3}$ leidt iedere keer tot nog meer verontrusting en nog meer wantrouwen tegenover de autoriteiten en instanties, vooral ook bij de media, die het als een uitdaging gaan beschouwen om de 'vele mysteries' rond de Bijlmerramp op te lossen. Dat leidt tot een stroom van berichten, soms gebaseerd op gedegen journalistiek onderzoek, maar soms ook op vermoedens, speculaties of zelfs geruchten. De uitkomsten van de parlementaire enquête staan in schril contrast met de opgewonden berichtgeving die al die 
jaren de indruk wekte dat er welhaast een verband moest bestaan tussen de 'Bijlmerzieken', het gif en de doofpot. Het toenemend aantal 'Bijlmerslachtoffers' leek die theorie lange tijd te bevestigen, maar terugkijkend is de vraag gerechtvaardigd of dat verband niet omgekeerd is. Misschien zijn wel steeds meer mensen gaan geloven in een link met de ramp juist onder invloed van de berichtgeving. Misschien zijn steeds meer mensen ziek geworden van het nieuws óver de ramp, in plaats van ziek dóór de ramp. Deze vraagstelling zullen we onderzoeken op basis van een analyse van de berichtgeving in 1998 en 1999 in de landelijke dagbladen en van gegevens over de manier waarop patiënten hun klachten zijn gaan definiëren.

\section{Media en risico amplificatie}

In de jaren na de fatale crash heeft de Bijlmerramp zich geleidelijk ontwikkeld tot een belangrijk 'risico issue'. De ramp bewees de kwetsbaarheid van complexe technologische systemen en ermee verbonden risico's voor de samenleving. In de nasleep kwam echter niet zozeer het risico van de landings- en aanvliegroutes boven dichtbevolkte gebieden centraal te staan, als wel de mogelijke gezondheidsrisico's die omwonenden en hulpverleners hadden gelopen tijdens en na de ramp. Dit maatschappelijk proces, waarbij een bepaald risico sterk wordt uitvergroot, staat in de literatuur bekend als de 'social amplification of risk.'

'Social amplification describes why some events seem to create ripple effects with secondary and tertiary impacts which spread beyond the initial effects of the hazard or event and impact upon previously unrelated technologies or institutions. Such impacts include demands for regulatory action, loss of trust in decision authorities or industry, and stigmatisation of a community or product or facility."s

Tijdens dit amplificatieproces worden bepaalde signalen telkens versterkt, terwijl andere worden afgezwakt, resulterend in een uitvergroting van een bepaald risico. Vervolgens zorgt dat weer voor nieuwe maatschappelijke ontwikkelingen, die op hun beurt dat risicoperspectief weer versterken. Allerlei sociale actoren kunnen een belangrijke rol spelen in dit amplificatieproces: de overheid, de medische sector, wetenschappelijke instituten, belangengroepen van slachtoffers - maar die van de media is cruciaal. Door hun manier van berichtgeven kunnen de media een versterkende, aanjagende rol gaan spelen, zeker als zich grote nieuwsgolven voordoen die het onderwerp hoog op de maatschappelijke agenda plaatsen. 
'The mass media can play a critical role in dramatizing and framing of the risk problem or threat. Particularly important are both the extent of coverage and the particular "facts" selected and the language used to characterize the risk. ${ }^{16}$

De invloed van de media is afhankelijk van factoren als de omvang en de intensiteit van de berichtgeving, de toonzetting, het woordgebruik, de invalshoek (bijvoorbeeld human interest) en de context waarin de feiten worden geplaatst. Uitgebreide media-aandacht voor een bepaald risico leidt tot meer verontrusting bij het publiek, dat alerter zal zijn op al die signalen die mogelijkerwijs een bevestiging van dat risico betekenen. Dat geldt ook weer voor de media, met als gevolg dat relatief onbetekenende feiten of kleine gebeurtenissen plotseling groot nieuws kunnen worden. De overheid zal op die publiciteit moeten reageren en dat geeft weer een nieuwe impuls. Op die manier kan er een zichzelf versterkend proces optreden, waarin mediahypes vol opwinding en verontwaardiging telkens zorgen voor versterking van een bepaald frame (ook wel collectieve voorstelling genoemd), bestaande uit analyses, perspectieven en typische voorbeelden. Bij een mediahype storten de media zich massaal op het onderwerp, maken dat steeds groter vanuit een centraal perspectief, oordelen en veroordelen ook meteen vanuit dat frame (er moeten koppen rollen), en jagen op nog meer bevestigend nieuws. Gedurende de hype vallen kritische geluiden en filters weg en wordt één geluid almaar versterkt. De oorzaak is dat media sterk 'self-referential' opereren en telkens nieuws van elkaar overnemen. Alle media-aandacht leidt vanzelf weer tot nieuwe 'feiten', daarmee het sociologische theorema bevestigend dat als mensen iets als 'waar' definiëren, ze er ook naar zullen handelen.

Dergelijke mediahypes liggen in het verlengde van de manier waarop de media in het algemeen omgaan met risico-onderwerpen: de nadruk in de berichtgeving ligt eerder op zeldzame, afwijkende, of 'exotische' gevaren dan op 'alledaagse' risico's als verkeersongevallen of hart- en vaatziekten. Rampen of ongelukken waarbij veel doden in één keer vallen, scoren hoog, met als gevolg dat de media-aandacht vaak omgekeerd evenredig is aan de feitelijke gezondheidsrisico's. In het nieuws draait het niet zozeer om een genuanceerde wetenschappelijke inschatting van de feitelijke gevaren, maar om schuld, angst, woede en verontwaardiging. Het gaat in de berichtgeving meer om 'outrage' dan om 'hazard'. Bronnen die alarm slaan krijgen meer aandacht dan deskundigen die geruststellende woorden spreken, extreme standpunten meer dan gematigde en opinies meer dan data. Vanwege de nieuwswaarde hebben de media een grote voorkeur voor 'worst case scenarios' in tijden van onzekerheid. De uitgebreide media-aandacht en de maatschappelijke verontrusting zorgen voor grote druk op de overheid om te reageren, ook al zijn de feitelijke risico's klein en is 'zero-risk' onmogelijk. P. Sandman: 
'The typical risk controversy comes when the hazard is low and the outrage is high. Captivated by the high outrage, the public insists the problem is serious; lulled by the low hazard, the utility insists it isn't. ${ }^{\text {"o }}$

Deze situatie levert voor de overheid een groot dilemma op: niet ingrijpen zal leiden tot een vertrouwenscrisis en het verwijt van de doofpot; wel drastische maatregelen treffen zal de ernst van de risico's definitief bevestigen. Vanuit hun waakhondfunctie zullen de media sterk gespitst zijn op een mogelijk falende overheid en dan vooral op het al dan niet ten onrechte achterhouden van informatie. Berichtgeving over risico's is dan definitief veranderd in berichtgeving over een schandaal, waardoor het inschatten van de feitelijke risico's naar de achtergrond verdwijnt.

\section{Media en het ontstaan van 'syndromen'}

Belangrijk in dit amplificatieproces is de interactie tussen de media en de mensen die direct bij de ramp betrokken zijn geweest. De slachtoffers voeden de media met hun verhalen, hun verontwaardiging en hun verontrusting. Aan de andere kant zorgen de berichten in de media vervolgens voor meer angst en onzekerheid bij deze en bij andere betrokkenen. Het gevolg kan zijn dat de berichtenstromen in de media een belangrijke bron van stress worden voor mensen die op de een of andere manier bij de ramp betrokken zijn geweest. Slachtoffers van een ramp lijden vaak enige tijd aan acute stress met symptomen als slaap- en concentratieproblemen, herbeleving en vermijdingsgedrag. Vervolgens ontwikkelt zich bij sommigen na enige maanden de posttraumatische stressstoornis (PTss)." De meest voorkomende symptomen hierbij zijn: obsessief bezig zijn met de ramp, emotionele vervlakking, slapeloosheid, hyperactiviteit of agitatie of prikkelbaarheid en concentratieproblemen. Onzekerheid over de mogelijke gevolgen voor de gezondheid, het gebrek aan erkenning, mogelijke arbeidsongeschiktheid, financiële problemen, herhuisvesting en de controverses in de media over deze kwesties vormen allemaal bronnen van stress die op de langere duur kunnen leiden tot nieuwe gezondheidsklachten of een versterking van de bestaande. ${ }^{12}$ De betrokkenen zullen het verergeren van de klachten eerder aan de ramp en de vrijgekomen gifstoffen toeschrijven dan aan een posttraumatische stressstoornis. Uit onderzoek blijkt dat het om een relatief klein repertoire aan klachten gaat zoals: hoofdpijn, moeheid, geheugenstoornis, pijn aan gewrichten en spieren, concentratieproblemen, benauwdheid en slaapproblemen. Dergelijke klachten komen niet alleen naar voren in de nasleep van grote rampen, maar ook na afloop van oorlogen als de Golfoorlog of de Nederlandse vredesmissies in Bosnië en Cambodja. 
Voor de artsen die deze mensen onderzoeken doet zich dan het probleem voor dat hun klachten doorgaans 'niet-specifiek' zijn, hetgeen wil zeggen dat ze ook veel voorkomen in de normale bevolking, waar ze nogal eens gerelateerd zijn aan psychische klachten als depressie. De diagnose 'PTSS' leidt bij de getroffenen doorgaans niet tot een grotere acceptatie van psychische gevolgen van de ramp of de oorlog die ze hebben meegemaakt. Integendeel, het verzet hiertegen is sterk en zeker na 'man-made' rampen is de neiging groot, zowel bij getroffenen als de media, om de verschillende symptomen te clusteren tot een syndroom of een ziektebeeld, dat is veroorzaakt door bijvoorbeeld de bij deze ramp vrijgekomen schadelijke stoffen. Dat sociale proces is telkens hetzelfde, alleen de labelling van de 'ziekte' verschilt, afhankelijk van de cultureel-maatschappelijke context. Zo was vroeger sprake van 'soldatenhart', of 'shell shock,' later van het Golfoorlogsyndroom, veroorzaakt door inentingen, munitie met verarmd uranium of Iraakse gifgassen.

Ook los van rampen en oorlogen kan dit collectieve verschijnsel van clustering en labelling optreden. In dat geval spreekt men van 'functionele somatische syndromen, ${ }^{13}$ waarbij de symptomen onder de noemer van een nieuwe ziekte worden gekoppeld aan biomedische verklaringen. De gezondheidsklachten zijn niet-specifiek, diffuus, ambigue en endemisch en komen in dezelfde mate ook voor in normale 'gezonde' populaties. Het gaat doorgaans om de zogenaamde 'unexplained physical symptoms' ('lichamelijk onverklaarde klachten'), om klachten als moeheid, concentratiestoornissen, problemen aan gewrichten, huid en luchtwegen. Bekende voorbeelden van op deze manier geconstrueerde syndromen zijn 'multipele chemische sensitiviteit', 'sick-building syndroom', 'chronische whiplash', 'fibromyalgie' en 'chronisch vermoeidheidssyndroom.' De syndromen kenmerken zich eerder door 'symptoms, suffering, and disability than by disease-specific, demonstrable abnormalities of structure or function. ${ }^{1 / 4}$ In het denken over de nieuwe ziekte ligt grote nadruk op biomedische verklaringen waarin de blootstelling aan giftige stoffen centraal staat. De syndromen houden zichzelf lange tijd in stand door een zichzelf versterkende cyclus: de angst voor een ziekte of de mogelijke gevolgen van besmetting of blootstelling zorgt voor een verhoogde gevoeligheid voor, een selectieve aandacht en een eenzijdige interpretatie van alreeds lang bestaande, 'onverklaarde' symptomen, die allemaal onder één noemer worden gebracht en die zo steeds ernstiger lijken te worden.

Als dit proces van clustering en labelling zich bij mensen voordoet die op dezelfde locatie zijn geweest (een school of een fabriek), spreekt men van 'mass psychogenic illness' of van 'mass sociogenic illness.' $\mathrm{Bij}$ deze 'sociale' epidemie gaan mensen van dezelfde groep elkaar telkens bevestigen in de overtuiging dat ze lijden aan een geheimzinnige aandoening, veroorzaakt door 
schadelijke stoffen. Er is meestal één concreet ziektegeval, de 'index-case', waarbij sprake lijkt te zijn van vergiftiging, vervolgens gaan steeds meer mensen dezelfde symptomen waarnemen en zich ook als slachtoffer van de nieuwe aandoening zien. Het komt echter zelden voor dat artsen de symptomen in zo'n groep ten onrechte diagnosticeren als 'psychogeen' terwijl er wel degelijk sprake is van blootstelling aan gifstoffen.

'Mass psychogenic illness' doet zich vooral voor bij groepen mensen die gebukt gaan onder een collectief gevoel van angst, onzekerheid, en vooral gebrek aan erkenning. Het idee slachtoffer te zijn van dezelfde ziekte schept een band, die telkens wordt versterkt als de groep zich manifesteert en in conflict raakt met (medische) instanties en overheden. Uit allerlei voorbeelden blijkt dat uitgebreid (lichamelijk) onderzoek naar mogelijke chemische of biologische oorzaken een averechtse uitwerking heeft op de getroffen groep, waarin zich vervolgens allerlei complottheorieën ontwikkelen, die moeten verklaren waarom de oorzaak van hun 'mysterieuze' ziekte niet gevonden 'mag' worden. Als er lange tijd voorbijgaat tussen de 'uitbraak' en het medisch onderzoek zal de groep weinig waarde hechten aan de conclusies van de onderzoekers, die overigens zelf ook nooit volledig zullen uitsluiten dat mensen zijn blootgesteld aan giftige stoffen, ook al zijn er geen bewijzen gevonden. Meestal komt er steun van buiten voor de groep: van alternatieve genezers, van dissidente artsen en gezondheidsexperts of van woordvoerders van actiegroepen, die een link willen leggen tussen deze 'ziekte' en hun strijd tegen kernenergie of pesticiden. Het resultaat is een vijandige houding tegenover de 'gevestigde' medische wereld, die voor het dilemma komt te staan dat wel of geen vervolgonderzoek doen in beide gevallen de groepsdynamiek zal aanjagen.

Bij mass psychogenic illness spelen de persoonlijke contacten binnen de groep een belangrijke rol, bij de functionele syndromen is aanvankelijk geen sprake van een samenhangende groep (die ontstaat pas later) en dus verloopt de communicatie via de media. De media kunnen bepaalde concepten (zoals bijvoorbeeld 'chronische vermoeidheid') 'populair' maken en ervoor zorgen dat mensen hun klachten vanuit dat kader gaan interpreteren.

Voor de media zijn de syndromen aantrekkelijk nieuws: het lijkt te gaan om een nieuwe, geheimzinnige ziekte die snel om zich heen grijpt en waar al veel mensen aan lijden. In de berichtgeving staat meestal de individuele patiënt centraal, zijn of haar lange zoektocht in de medische wereld, het gebrek aan erkenning en de invaliderende effecten van de ziekte. Vanuit één specifiek geval wordt vrij makkelijk gegeneraliseerd naar een grote groep. Mensen met uiteenlopende klachten kunnen zo onder één noemer worden gepresenteerd. 'Human interest' staat centraal, terwijl voorlopige data, hypothesen en vermoedens al snel de status krijgen van medisch bewijs. ${ }^{16}$ In de berichtgeving ligt een sterke nadruk op het vinden van een 
biomedische verklaring, bij voorkeur een (alledaagse) chemische substantie die een vergiftiging kan opleveren. Toezeggingen van de kant van de overheid om onderzoek te doen worden geïnterpreteerd als bevestiging van de gifhypothese. Er is doorgaans maar weinig aandacht voor psychosociale verklaring en voor de dynamiek zelf rond de ontwikkeling van een syndroom.

\section{De Bijlmerzieken en het Bijlmersyndroom}

Gedurende de lange nasleep van de Bijlmerramp groeit het aantal 'Bijlmerzieken', zoals ze in de media worden genoemd, maar bij nader inzien gaat het om verschillende groepen die zich op verschillende momenten melden en die in de loop der jaren telkens in omvang toenemen. Het gaat in de eerste plaats, vanaf 1993 , om hulpverleners die op de rampplek actief zijn geweest, Bijlmerbewoners die hun woning moesten verlaten en mensen die de ramp zagen gebeuren. Daarnaast is er een groep bewoners en passanten die in de nabijheid (maar op enige afstand) van de rampplek waren. Later, vanaf 1998, komen daar bij de medewerkers van het bedrijf dat het puin en de vervuilde grond heeft afgevoerd en verbrand. En tenslotte zijn er, vanaf 1998 , de KLM-medewerkers die in hangar 8 hebben gewerkt waar de brokstukken van de verongelukte Boeing tijdelijk waren opgeslagen. De gezondheidsklachten van deze Bijlmerzieken zijn zeer uiteenlopend en slechts in uitzonderingsgevallen is sprake van een identificeerbare aandoening, zoals bijvoorbeeld een auto-immuun ziekte, een verzamelterm van ziekten, zoals SLE en Vasculitis waarbij anti-lichamen worden aangemaakt tegen lichaams-eigen weefsel.

Deze gevallen vertonen geen overeenkomsten, terwijl een causale relatie met de ramp niet kan worden aangetoond. $\mathrm{Bij}$ de grote groep mensen met gezondheidsproblemen gaat het om klachten als: chronische vermoeidheid, concentratie- en geheugenverlies, gewrichtsproblemen, spierpijnen, ademhalingsproblemen, slapeloosheid, hoge bloeddruk, eczeem, haaruitval, rode vlekken, jeuk, huiduitslag, enzovoort. Daarbij gaat het overigens voor een deel om klachten die al vóór oktober 1992 (elf procent van de AMC-onderzoeksgroep) of pas vanaf 1998 (vijftien procent) bekend waren bij de huisarts. Opmerkelijk is ook dat het niet alleen bewoners zijn uit de omliggende flats of hulpverleners die op de rampplek actief waren, maar ook mensen die niet in de buurt van de rampplek zijn geweest.

Een aanwijsbare fysieke oorzaak wordt na individueel medisch onderzoek door huisarts of specialist niet aangetroffen, maar dat neemt de bezorgdheid bij de patiënten niet weg, integendeel, de ongerustheid neemt toe, zeker als zich steeds meer mensen met klachten blijken te melden. Uit 
de resultaten van het AMC-onderzoek in 1998 blijkt dat de klachten zeer divers zijn, dat er geen klachtenpatronen zijn die wijzen op specifieke ziektes of aandoeningen en dat in vrijwel alle gevallen al medische hulp is gezocht. ${ }^{17}$ "Huisartsen meenden dat de belangrijkste oorzaak voor het ontstaan van klachten de traumatische ervaring op zichzelf is, daarna gevoed door de media. ${ }^{18}$ Deze conclusies komen overeen met tal van ander onderzoek waaruit blijkt dat mensen na rampen een vast repertoire aan psychische en (niet-specifieke) lichamelijke klachten rapporteren, waarbij zelden een klinische samenhang of biologische basis wordt gevonden. Ook bij de Bijlmerslachtoffers kon geen eenduidige, klinisch relevante organische oorzaak voor de klachten worden gevonden. Wel blijkt dat mensen hun klachten toeschrijven aan aandoeningen die anderen ook rapporteren.

Dit wijst allemaal op het clusteren en labelen van algemene, stressgerelateerde gezondheidsklachten tot een Bijlmersyndroom in de betekenis van een functioneel somatisch syndroom. Daarnaast is er een kleinere groep die een ernstige ziekte (bijvoorbeeld kanker) heeft en die de oorzaak bij de ramp legt. Duidelijk is dat er in de onzekere en onrustige nasleep van de ramp een sterke en langdurende toename was van psychische symptomen ('distress') bij mensen die betrokken waren bij de ramp of in de nabijheid van de rampplek woonden. Bij de KLM-medewerkers van hangar 8 lijkt vooral sprake te zijn geweest van 'mass psychogenic illness', waarbij één ziektegeval aanleiding is voor een hausse aan klachten bij 'honderden' medewerkers. Uit verkenningen blijkt dat uitgebreid onderzoek om de patiënt gerust te stellen juist een averechts effect heeft en hem bevestigt in de overtuiging ernstig ziek te zijn. Door de onzekerheid over de lading van de ramp-Boeing deden huisartsen in de Bijlmer eerder meer onderzoek dan minder en verwees men vaker door naar een specialist. Het is duidelijk dat bij verschillende groepen Bijlmerzieken na verloop van tijd de stressgerelateerde en de (endemische) 'lichamelijk onverklaarde klachten' niet meer van elkaar te onderscheiden zijn. Bovendien levert de lange nasleep en het gevoel niet erkend te worden als Bijlmerslachtoffer weer nieuwe stress op die kan leiden tot nog meer klachten. Aan dat proces heeft de rumoerige berichtgeving in 1998 en 1999 een belangrijke bijdrage geleverd.

\section{Mediahypes in de Bijlmerberichtgeving}

In maart en april en in september en oktober 1998 doen zich twee grote mediahypes voor, eerst rond het verarmd uranium en later rond de Sarin grondstoffen. (Zie grafiek I). 


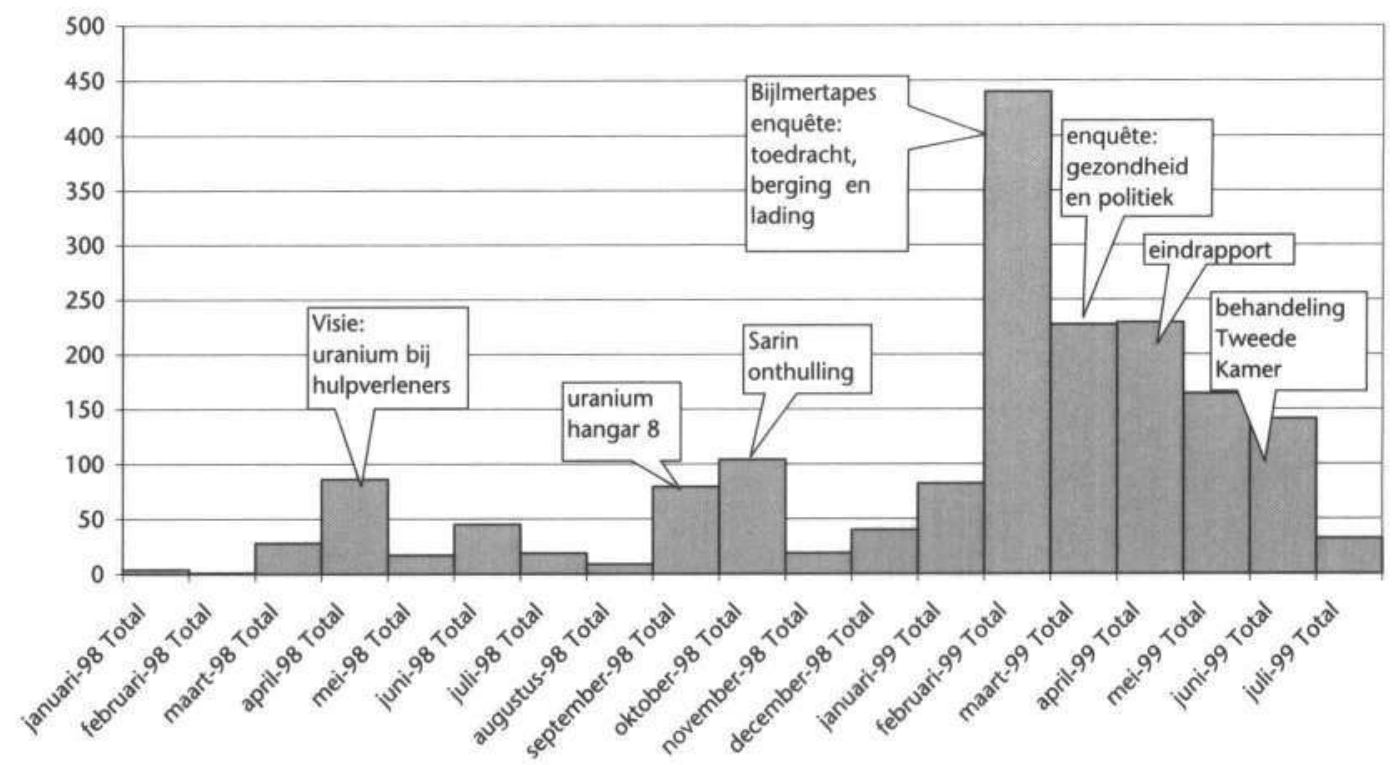

Grafiek 1 Aantal artikelen per maand in de vijf landelijke dagbladen plus Het Parool,1998 - medio 1999

Beide keren treedt dezelfde dynamiek in werking: hoewel de oorspronkelijke aanleiding op z'n minst discutabel is voor wat betreft feiten of presentatie (grondstof is niet hetzelfde als zenuwgas Sarin), creëren de media een nieuwsgolf door follow-upste maken over de gezondheidsklachten, het wantrouwen ('Onze verhalen zijn nooit geloofd.' Algemeen Dagblad, 30 maart 1998), de ontbrekende antwoorden, de reacties van de politiek en de gevaren van biologische wapens. Telkens komen er nieuwe flarden van informatie beschikbaar die door het fragmentarische karakter alleen maar meer vragen oproepen. Daarbij is weinig aandacht voor uitspraken en feiten die in een andere richting wijzen; alles lijkt te moeten passen in een centraal frame, namelijk dat van het 'ziekmakend gif in de doofpot': de giftige lading van de Boeing (inclusief verarmd uranium) is de belangrijkste oorzaak van de vele gezondheidsklachten, de getroffenen zijn jarenlang om de tuin geleid, hun klachten werden niet serieus genomen, de overheid heeft allerlei informatie achtergehouden, dan wel geen pogingen gedaan de waarheid over de lading te achterhalen, er is sprake van een reeks van doofpotten rond de vliegramp die heeft geleid tot een vertrouwensbreuk tussen Bijlmergetroffenen en de overheid. De toepassing van dit frame blijkt niet alleen uit de nieuwskeuze en het construeren van een context, maar vooral ook uit het woordgebruik. Typische termen zijn: 'Bijlmerzieken', Bijlmerslachtoffers', 'gif, 'straling', 'kankerverwekkend', 'lichamelijk onderzoek', 'wantrouwen', 'argwaan', 'erkenning', 'ongerustheid', 'onzekerheid', 'frustratie', 'raadsels', 'raadselachtig', 'mysteries', 'geheimzinnig', 'onverklaarbaar', enzovoort. De dominan- 
tie van het gif/doofpot frame hangt samen met de frequentie waarmee bepaalde bronnen (Visie, Bijlmerslachtoffers, advocaten, enzovoort) in dat nieuws voorkomen. Andere woordvoerders zien zich vervolgens gedwongen om te reageren in de termen van het frame, dat daardoor weer wordt versterkt.

Daarnaast komt in de berichtgeving ook nog een ander frame voor, namelijk dat van de 'debunking', dat stelt dat er nog veel onopgeloste vragen rond de ramp zijn en dat de overheid veel te verwijten valt, maar dat er geen reden is om geruchten en onbevestigde berichten te publiceren of voetstoots aan te nemen dat de gezondheidsklachten veroorzaakt zijn door giftige stoffen. De veronderstelde gezondheidsrisico's zijn overdreven, dan wel wetenschappelijk slecht onderbouwd, media laten zich te snel op sleeptouw nemen door belangengroepen. Dit frame komt wel aan bod in commentaren, opiniestukken en achtergrondverhalen, maar is in de minderheid en het ontbreekt vooral in de dagelijkse nieuwsstroom, die meer gericht is op de activiteiten van de betrokken sociale actoren. Als er feiten in het nieuws komen die het centrale frame weerspreken, worden ze wel gemeld, maar blijft het bij eenmalige publicaties. Op zes november bijvoorbeeld maakt het RIVM (Rijksinstituut voor de Volksgezondheid en Milieuhygiëne) bekend dat het risico dat mensen kanker hebben opgelopen door het inademen van verarmd uranium of andere zware metalen 'verwaarloosbaar klein' is. Dit onderzoek levert in ieder dagblad maar één, meestal kort, artikel op, maar vervolgnieuws komt er daarna niet uit voort. Met andere woorden, de gebruikelijke dynamiek die optreedt bij 'frame bevestigend nieuws' blijft hier achterwege. Het gif/doofpot frame domineert de berichtgeving en het wachten is op de grote doorbraak waar de parlementaire enquête in 1999 voor moet gaan zorgen.

Ook de berichtgeving over de 'Bijlmergetroffenen' is in deze periode eenzijdig en onkritisch. Het zijn telkens dezelfde mensen die als woordvoerder optreden, maar de rest blijft tamelijk onzichtbaar en anoniem in de berichtgeving. Zij vormen de verpersoonlijking van de grotere groep waarover voortdurend wordt gegeneraliseerd: in de verhalen over deze mensen staan vaak verwijzingen naar de grotere groep, naar collega's of andere buurtbewoners die ook allemaal vergelijkbare klachten hebben. Er is sprake van 'veel slachtoffers' met een 'reeks van onverklaarde klachten.' De klachten die in de verhalen van de slachtoffers aan bod komen zijn vrijwel identiek: het gaat om de bekende verschijnselen als vermoeidheid, aanvallen van benauwdheid, slapeloosheid, hoge bloeddruk, eczeem, haaruitval, nachtmerries, rode vlekken, jeuk, huiduitslag, vergeetachtigheid, long- en oogklachten, vaak verkouden, pijn op de borst en in de botten, spierontstekingen, enzovoort. De in de media telkens terugkerende opsommingen suggereren een samenhangend klachtenpatroon als gevolg van dezelfde ziekte. Wie 
welke klachten heeft blijft tamelijk onduidelijk, wel komt altijd aan de orde dat de artsen meestal geen fysieke oorzaak kunnen vinden en daarom concluderen dat het dan wel 'psychisch' zal zijn. De conclusie van het AMC dat er geen clusters van klachten voorkomen wordt dan ook geïnterpreteerd als een weigering om de 'slachtoffers' te onderzoeken en te behandelen. In feite zijn Bijlmerbewoners met ernstige klachten wel degelijk in behandeling, onder andere bij artsen van het AMC. De verslaggevers gebruiken doorgaans geen andere bronnen om het verhaal van het slachtoffer te controleren. Als er al specialisten of deskundigen in het verhaal voorkomen, doen ze alleen in algemene zin uitspraken over stressgerelateerde klachten, uitspraken die door de slachtoffers weer worden bekritiseerd als gebrek aan erkenning. Het gebrek aan erkenning door de overheid en de medische stand is de invalshoek, niet de opvallende overeenkomsten met andere syndromen die dezelfde lijstjes met algemene klachten opleveren, zoals het Golfoorlogsyndroom. Uit de slachtofferverhalen blijkt geen kritische journalistieke houding, eerder een sterke identificatie met het leed van de ondervraagden en hun subjectieve beleving.

Bij de start van de openbare verhoren op 27 januari 1999 door de parlementaire enquêtecommissie breekt een nieuwe fase in de berichtgeving aan. De Bijlmer zal vanaf dat moment maandenlang de voorpagina's en de openingen van radio en televisiejournaals en actualiteitenrubrieken beheersen. Bovendien maakt de enquête veel reacties los, eerst woede en verbijstering, maar na het publiceren van het eindrapport op 22 april 1999, voornamelijk teleurstelling. De media hebben in die maatschappelijke dynamiek een zeer belangrijke rol gespeeld, niet alleen door de dagelijkse verhoren te verslaan, maar ook door het reconstrueren van het grotere geheel waarin al die losse puzzelstukjes mogelijk zouden kunnen passen. ${ }^{19} \mathrm{Gezien}$ de voorgeschiedenis is het niet verbazingwekkend dat het 'gif/doofpot' frame daarbij centraal staat.

De eerste week van de verhoren staat vooral in het teken van de verhalen van slachtoffers en hulpverleners die zeggen ernstige gezondheidsklachten te hebben sinds de ramp. Voor mensen met een auto-immuunziekte is dit aanleiding om het AMC-meldpunt te bellen:

'Mijn dokter heeft mij twee maanden geleden verteld dat ik een autoimmuunziekte heb. Ik werkte in de buurt van de rampplaats en zag gisteren op de tv dat er nog meer mensen zo'n ziekte hebben.'

De grote 'onthulling' die enkele dagen later, op woensdag drie februari, volgt lijkt het gif/doofpot scenario volledig te bevestigen. Dan blijkt namelijk dat er een 'vergeten' geluidsband is ontdekt, waarop te horen is dat de verkeersleiders op de rampavond bellen met een $\mathrm{El} \mathrm{Al-medewerker} \mathrm{over} \mathrm{de}$ 
lading. Die leest eerst de vrachtbrief voor en vraagt vervolgens aan de luchtverkeersleider over de lading geen mededelingen te doen, waarop deze dat toezegt: 'Dat zullen ze niet van ons horen.' D66-kamerlid Augusteijn leest langzaam het citaat van de $\mathrm{El} \mathrm{Al}$-medewerker voor:

'Er zat een behoorlijke hoeveelheid explosieven aan boord, cartridges. Er zat gif aan boord. Er zaten gassen aan boord, niet gevaarlijk, brandbare gassen. Brandbare vloeistoffen.'

Uit het verhoor, dat zich toespitst op het 'onder de pet' houden van deze informatie (vanaf dat moment een gevleugelde uitdrukking in de Bijlmerberichtgeving), blijkt nergens enige twijfel over de correctheid van die informatie. Het nieuws van de 'Bijlmertapes' slaat vervolgens in als een bom; er is eindelijk een grote doorbraak in het Bijlmerdrama en dat leidt tot krachtige koppen. 'Zes jaar belazerd', meldt het Algemeen Dagblad (4 februari 1999). 'Bijlmerramp: de doofpot gaat open. Gevaarlijke lading verzwegen, hulpverleners onbeschermd, justitie gelast onderzoek.' Aldus Trouw (4 februari 1999). 'Woede om doofpot El Al-gif' meldt De Telegraaf (4 februari 1999): 'Een schokkende en verbijsterende affaire die gisteren terecht een golf van verontwaardiging door het land deed gaan.' Veel aandacht is er ook voor de reacties van de Bijlmerslachtoffers:

'Bewoners van de Bijlmer en hulpverleners hebben gisteren geschokt en met woede gereageerd op de onthulling dat de luchtverkeersleiding al een half uur na de ramp wist dat er gevaarlijke lading aan boord was. Tegelijkertijd is er ook opluchting omdat de gezondheidsklachten die veel bewoners aan de lading wijten, nu waarschijnlijk eindelijk serieus zullen worden genomen.'

Aldus het Algemeen Dagblad (4 februari 1999).

Het 'onder de pet houden' zorgt voor een mokerslag die de daaropvolgende berichtgeving totaal gaat beheersen. De stroom van woedende reacties en beschuldigingen leidt tot een breed uitgemeten collectieve verontwaardiging. Het eindeloos herhalen van het nieuws over de geluidsband versterkt het gevoel dat de waarheid eindelijk boven water komt en dat de enquête daarmee zijn bestaansrecht al na een week heeft bewezen. De verontwaardiging in de media is zo groot dat alle onzekerheden en twijfels wegvallen en dat het 'schandaal' nog eens extra zwaar wordt aangezet. Getuigen veranderen al snel in verdachten, zoniet schuldigen.

Uitspraken in latere verhoren dat de $\mathrm{El} \mathrm{Al}$-medewerker de verkeerde lijst heeft voorgelezen worden door de commissie en de media dan ook niet serieus genomen. De reactie van Kok en Netelenbos om drie verkeersleiders 
en de voormalige directeur-generaal van de Rijksluchtvaartdienst te schorsen is voor de media het definitieve bewijs van de doofpot. Slechts sporadisch houden de media een slag om de arm of nuanceren ze het begrip 'gevaarlijke stoffen': cosmetica en parfum vallen daar in luchtvaarttermen ook onder. De letterlijke tekst van de Bijlmertapes komt pas enkele dagen later naar buiten en dan blijkt dat het verzoek om geen mededelingen te doen over de lading bedoeld is om speculaties over de oorzaak van de ramp (het vliegtuig zou in de lucht zijn ontploft) tegen te gaan. Verder gaat het in een moeilijk verstaanbare passage niet om 'geen uitspraken doen over het aantal vracht...', maar om 'slachtoffers', zoals later ook wordt bevestigd door de El Al-medewerker (de Volkskrant 5 maart 1999). De media zijn allemaal nog volledig in de ban van de giffen, gassen en explosieven als de Volkskrant een week later na het bestuderen van de gevaarlijke stoffenlijst en de ladingsplattegrond onthult dat de 'Ramp-Boeing geen explosieven vervoerde' (Io februari 1999). De andere media nemen dat nieuws niet over en blijven nog dagenlang vasthouden aan de Bijlmertapes. Pas aan het eind van die week begint het besef door te dringen dat, zoals NRC Handelsblad schrijft, het bericht over de gevaarlijke lading 'non-informatie' was: 'In het NOS-JOuRNAAL erkende ook voorzitter Th. Meijer dat dit nieuws "een lading heeft gekregen die achteraf misschien anders had moeten worden gebracht."' Ook al groeit de twijfel over de gevaarlijke lading, voor de meeste media is dat nog geen reden voor een koerswijziging: het 'onder de pet houden' is nu het 'werkelijke' schandaal, niet de mogelijke gezondheidsrisico's. Dit leidt tot een reeks van artikelen over de vraag of ministers, topambtenaren of andere gezagsdragers al dan niet op de hoogte waren van bepaalde informatie, of ze die hadden moeten hebben en of ze er iets anders mee hadden moeten doen dan ze deden. De media blijven de enquête wekenlang verslaan vanuit de optiek dat er nog steeds een groot (gezondheids-) schandaal in de maak is. Het is duidelijk dat ook de enquêtecommissie medeverantwoordelijk is voor deze beeldvorming door telkens hierop door te vragen, alsof er nog steeds sprake was van een giftige lading.

Dat blijkt vooral tijdens de verhoren in de week van de gezondheid, begin maart. De verslaggevers lijken zich - gesteund door de commissie - te willen vastklampen aan iedere aanwijzing dat de lading, het verarmd uranium of dan maar de hele kerosinebrand de gezondheidsklachten 'moeten' hebben veroorzaakt. Vanuit dat perspectief wordt selectief geciteerd uit de verhoren. Geruststellende, relativerende informatie wordt genegeerd, gebagatelliseerd of ontkracht door verontrustende koppen, zoals: 'Veel meer zieken door Bijlmerramp' (De Telegraaf, 5 maart 1999). Ook al hebben alle onderzoekers in deze week uitgesloten dat het verarmd uranium extra gezondheidsrisico's heeft veroorzaakt, is dat niet het beeld dat uit de berichtgeving naar voren komt. 'Uranium oorzaak Bijlmerklachten,' (6 maart 
1999) meldt De Telegraaf op basis van een uitspraak tijdens een verhoor dat auto-immuunziekte veroorzaakt 'kan worden door toxische stoffen.' Dat 'opvallend hoge' aantal gevallen van auto-immuunziekte is op dat moment nog het enige concrete aanknopingspunt voor het gezondheidsschandaal. In de berichtgeving over de verschillende onderzoeken naar de gezondheidsrisico's rond de brand valt op dat minimale interpretatie- en meningsverschillen breed worden uitgemeten, ten koste van de aandacht voor de conclusies waarover wetenschappelijke consensus bestaat, namelijk dat de brand noch het uranium extra gezondheidsrisico's heeft opgeleverd. ${ }^{20}$ De verhoren waarin posttraumatische stressstoornissen of de resultaten van het AMC-gezondheidsonderzoek aan bod komen, krijgen in de media nauwelijks aandacht. Daardoor blijft verwarring bestaan over 'de weigering van het AMC om een gericht lichamelijk onderzoek uit te voeren,' zoals de standaardformulering luidt. Het AMC is inderdaad tegen een grootschalig lichamelijk onderzoek, maar iedereen met klachten is onderzocht en wordt of werd behandeld. Wanneer half april na afloop van de enquête, maar nog voor het verschijnen van het eindrapport, de derde tussenrapportage van het AMC-onderzoek bekend wordt gemaakt, reageren de media buitengewoon gereserveerd, terwijl hierin toch het vermeend hoge aantal auto-immuun aandoeningen sterk wordt genuanceerd.

De presentatie van het eindrapport van de Parlementaire Enquête Commissie op 23 april is uiteraard zeer groot nieuws, want daarin staat dat de opeenvolgende kabinetten de Tweede Kamer 'onduidelijk, onvolledig, ontijdig of onjuist' hebben geïnformeerd over de Bijlmerramp. In de media is waardering voor het boven water tillen van de lading documentatie en het ontzenuwen van tal van geruchten en complottheorieën, maar daar staat tegenover dat nog vele vragen onopgelost blijven. De berichtgeving concentreert zich vervolgens meteen op de vraag of er in de politiek koppen gaan rollen. Wat de gezondheidsklachten betreft komt Beladen vlucht niet tot heldere conclusies. Het rapport stelt dat er 'een directe relatie tussen gezondheidsklachten en de ramp in de Bijlmermeer bestaat' en dat 'traagheid en onderschatting (...) de gezondheidsklachten in aantal en aard heeft doen toenemen.' Maar om welke klachten het bij deze algemene conclusies precies gaat - stress-gerelateerd of veroorzaakt door gif? - is niet duidelijk. De commissie concludeert wel dat voor 'grote groepen geen chronische gezondheidsklachten voortgekomen zijn uit de vrijgekomen schadelijke stoffen' en dat er 'een directe relatie (bestaat) tussen psychische klachten, waaronder PTss, en de Bijlmerramp,' maar zij sluit niet uit dat (enkele) individuen chronische gezondheidsklachten hebben opgelopen door bijvoorbeeld het inademen van uraniumoxide. Maar welke 'Bijlmerzieken' in welke categorieën thuishoren, dat blijft volstrekt onduidelijk. Als 'individuen' wel een uraniumbesmetting kunnen hebben opgelopen, betekent dat dan dat de 
overige groep met dezelfde klachten - zoals de hele hangar 8 groep - in de categorie 'psychisch' thuishoort? Daar doet de commissie geen uitspraken over, terwijl het voor de hand ligt dat zich bij de KLM-medewerkers een typisch geval van 'mass psychogenic illness' heeft voorgedaan.

Het is niet verbazingwekkend dat de berichtgeving over de gezondheidsklachten en de ramp even vaag is als het eindrapport. $\mathrm{Er}$ is voortdurend sprake van 'de gezondheidsklachten' en de 'Bijlmerzieken' zonder een duidelijk onderscheid tussen PTSs-gerelateerde klachten en somatische aandoeningen, mogelijk als gevolg van gif. Ook is in de berichtgeving niet duidelijk welke klachten in 'aard en omvang' ernstiger zijn geworden in de loop der jaren. De berichtgeving suggereert dat mensen jarenlang op medische behandeling van hun 'ziekte' hebben moeten wachten, terwijl er bij nader inzien voornamelijk sprake is van psychische klachten. De relatie tussen de ramp en de auto-immuunziekten wordt bovendien als een vaststaand feit gemeld, terwijl de commissie dat 'niet uitsluit,' en AMC-specialisten de relatie afwijzen. Zo blijft het 'gif/doofpot' frame nog steeds doorwerken in de berichtgeving, ook al heeft het eindrapport definitief afgerekend met tal van speculaties over verarmd uranium, mannen in witte pakken en plutonium.

Behalve een grote nadruk op het gif/doofpot frame valt in de berichtgeving tijdens de enquête ook op dat de verschillende media hun eigen koers varen, waarbij onthullingen van de concurrentie worden genegeerd. Bovendien trekken sommige dagbladen gezamenlijk op met belanghebbende bronnen.

Een voorbeeld daarvan is de nauwe samenwerking tussen De Telegraafen de als 'privé-onderzoeker' aangeduide L. Bertholet, die telkens met onthullingen komt rond het genetisch gemodificeerd mycoplasma, de mannen in witte pakken en natuurlijk de (nog steeds) explosieve, giftige lading. Bij drie Bijlmerslachtoffers zou sprake zijn van een mycoplasma-besmetting, een 'gemene onzichtbare bacterie' die bewijst 'dat het rampvliegtuig gevaarlijke chemicaliën voor chemische en biologische oorlogsvoering aan boord had.' De mycoplasma-theorie wordt niet serieus genomen, door de commissie, noch door de andere media. Hetzelfde lot zijn andere door Bertholet geïnspireerde onthullingen van De Telegraaf beschoren, zoals bijvoorbeeld dat de mannen in witte pakken lid zouden zijn van een speciale defensie-eenheid en dat verschillende militairen inmiddels ernstig ziek zouden zijn.

Een andere krant met discutabele onthullingen die niet door andere media worden overgenomen, is Trouw. Volgens deze krant zou de Boeing een nucleaire lading hebben vervoerd en is in de hangar 8 op Schiphol Cesium-137 aangetroffen, dat 'gevaarlijk is bij huidcontact en inademing en na jaren huid- en eierstokkanker kan veroorzaken.' Een dag later meldt Trouw dat het Cesium een overblijfsel is van de kernramp in Tsjernobil in 1986 en dat er geen sprake is van risico's. 


\section{Ziek van het nieuws?}

Deze eenzijdige, door mediahypes beheerste berichtgeving heeft duidelijk invloed op het aantal mensen dat zich telkens aanmeldt voor een gezondheidsonderzoek. In juni 1998 is het meldpunt van het AMC van start gegaan, waarbij zich meteen 6ri mensen aanmelden. In de maand juli stijgt dat aantal tot $839 \mathrm{om}$ in oktober na de opwinding over de Sarin-grondstoffen uit te komen op ro 72 mensen. Golven van nieuws blijken telkens duidelijk samen te hangen met nieuwe golven 'Bijlmerzieken.' De intensieve berichtgeving gaat telkens vóóraf aan de toenames van het aantal mensen dat klachten meldt. Normaal gesproken zou men het omgekeerde verwachten, namelijk dat er eerst meer ziekmeldingen komen en dat dan pas de aandacht van de media toeneemt. Dat de instelling van een telefonisch meldpunt leidt tot een toestroom van mensen met klachten is vanzelfsprekend, zeker omdat het АMC op allerlei manieren mensen heeft opgeroepen om deel te nemen. Minder voor de hand liggend is dat er in de maanden daarna telkens nieuwe groepen 'Bijlmerzieken' bijkomen, die zich daarvoor nooit hebben gemeld. Dat zijn sterke aanwijzingen voor de veronderstelling dat de golven van verontrustend nieuws, bijvoorbeeld over Sarin-grondstoffen, mensen op het idee brengen om zich te melden. Soms verwijzen zij daarbij direct naar die berichtgeving, zoals deze bellers in oktober 1998 :

'Nu ik gelezen heb dat er troep in het vliegtuig zat, wil ik me nog aanmelden voor het AMC-onderzoek, omdat ik sinds de ramp altijd heel moe ben geweest en ik nu snap waarom.'

'Ik wil me nog aanmelden voor het onderzoek. Ik had het er gisteren nog met mijn vrouw over: heb me eigenlijk nooit meer goed gevoeld, nadat ik naar de ramp was gaan kijken.'

Het patroon van nieuwsgolven en telkens nieuwe groepen die zich als Bijlmerzieken gaan melden zal zich tijdens de parlementaire enquête nog enkele malen voordoen. In de dagen na de onthulling van de Bijlmertapes komen bij het AMC honderden telefoontjes binnen van bezorgde, angstige mensen. 'Onder hen zijn veel mensen met een ernstige ziekte, die nooit een relatie met de ramp zagen, maar zich aanmelden onder het motto "je weet maar nooit." ${ }^{\text {'2 }}$ Het AMC besluit in februari tot het instellen van een speciaal call center waar in totaal een kleine duizend mensen naar toe zullen bellen. Bij de Stichting Korrelatie die op verzoek van de Enquêtecommissie telefoonlijnen open had in februari tot en met begin maart, komen in die vijf weken in totaal 692 telefoontjes binnen. Maar het meest in het oog springend is misschien wel de verdriedubbeling van het aantal mensen met klach- 
ten bij de start van het Medisch Onderzoek Vliegramp Bijlmermeer, direct na de parlementaire enquête in maart 1999. Uiteindelijk, voorjaar 1999, zal de teller op 6430 mensen blijven steken.

In tijd gaan de mediahypes dus telkens vooraf aan toenames van klachten. (Zie grafiek 2).

'Vreselijk wat ik nu gehoord heb. Ik ben destijds op de rampplek wezen kijken en heb nu kanker. Ik denk dat ik nu wel weet waar ik dat heb opgelopen, denkt u ook niet? Je weet het nooit.'

'Heeft u gisteren de krant gelezen? Mijn dochter heeft sinds de ramp last van haaruitval. Ik had haar altijd gesust, maar nu weet ik wel beter.'

Het feit dat deze mensen zich nooit eerder hebben gemeld, bijvoorbeeld voor het AMC-onderzoek in 1998, is een sterke aanwijzing voor een mediaeffect. Blijkbaar zijn zij pas na de gigantische mediahype over de giftige lading in de eerste week van februari op het idee gekomen om een verband te leggen tussen de ramp en hun gezondheidsklachten. In de berichtgeving overheerst dan het beeld dat er eindelijk een grote doorbraak is bereikt rond de 'onder pet gehouden' lading en de gezondheidsklachten.

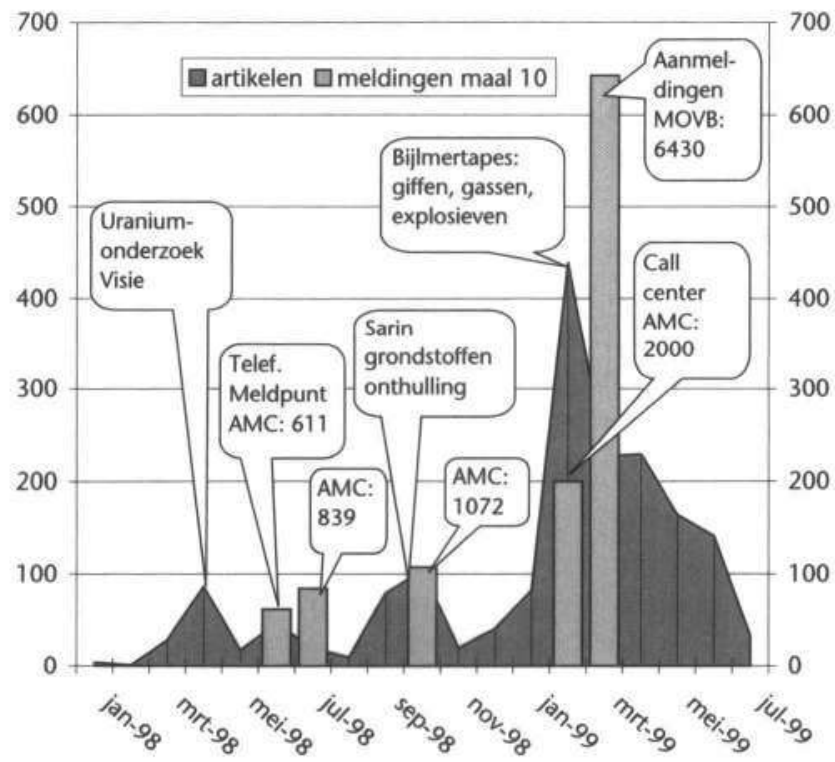

Grafiek 2 Aantallen artikelen in de Volkskrant, Algemeen Dagblad, Trouw, De Telegraaf, NRC Handelsblad en Het Parool per maand en aantallen mensen die gezondheidsklachten melden 
Uit tussenrapportages $^{22}$ van het Medisch Onderzoek Vliegramp Bijlmermeer (моув) voorjaar 2002 blijkt dat circa een kwart (IIоO) van de 4800 deelnemers is geadviseerd om zich via de huisarts door te laten verwijzen naar de speciale nazorg van het Advies- en Behandelcentrum Nazorg Vliegramp Bijlmermeer. Daarmee komt het моvв na alle inspanningen weer uit bij het oorspronkelijke aantal van het AMC-onderzoek van juli 1998. Bij driekwart van de onderzochte groep is geen enkele aanwijzing gevonden voor klachten als gevolg van de ramp. Dat is een belangrijke aanwijzing voor de hypothese dat duizenden mensen door de berichtgeving op het idee gebracht zijn om hun (bestaande) ziekte of (vage) gezondheidsklachten in verband te brengen met de ramp, en dan vooral met de vermeende giftige stoffen. Vermoedelijk heeft de berichtgeving ook bijgedragen aan het verergeren van de PTSS-gerelateerde klachten bij bewoners en hulpverleners die vanaf het begin betrokken zijn geweest bij de Bijlmeraffaire.

De beeldvorming tijdens de parlementaire enquête kwam uiteraard niet uitsluitend voor rekening van de media. De enquêtecommissie had voor een groot deel de regie zelf in handen; zij bepaalde de volgorde van de verhoren, de vraagstellingen en de toonzetting rond bijvoorbeeld de Bijlmertapes. Door het uitgebreide vooronderzoek had de commissie een grote voorsprong op de media die voor de moeilijke opgave stonden om allerlei uitspraken tijdens de verhoren op waarde te schatten en in een breder kader te plaatsen. Aan de andere kant konden de media de verleiding niet weerstaan om allerlei zeer voorlopige brokjes informatie onmiddellijk in het centrale gif/doofpot frame te passen en daar meteen conclusies aan te verbinden. Met als gevolg een grote mediahype vol verontwaardiging over de Bijlmertapes, die een zakelijke verslaggeving van de enquête daarna vrijwel onmogelijk maakte. In dat opzicht sluit de berichtgeving tijdens de enquête naadloos aan bij de hypes in 1998 over het verarmd uranium en de Sarin-grondstoffen. Ook ten aanzien van de gezondheidsklachten vormt de periode van de enquête een voortzetting van de ontwikkelingen in 1998. $\mathrm{Na}$ iedere mediahype melden zich telkens weer nieuwe groepen mensen die hun gezondheidsklachten in verband brengen met de Bijlmerramp. In hun verhalen komen talrijke verwijzingen voor naar de berichtgeving over de mogelijke giftige stoffen. De conclusie dat het grootste deel van de Bijlmerzieken eerder ziek geworden is van het nieuws over de ramp dan van de ramp zelf zou in de media moeten leiden tot een bezinning op de verslaggeving over rampen en gezondheidsrisico's. Temeer daar de Bijlmeraffaire tien jaar na de ramp weer terug bij af lijkt te zijn. Er is nog steeds onrust in de Bijlmer, er heerst nog steeds een gevoel van miskenning en er zijn nog steeds allerlei geruchten. Rond de herdenking op 4 oktober 2002 duiken die verhalen ${ }^{23}$ over mysterieuze ziektegevallen, mannen in de witte pakken en geheime diensten ook weer op in de 
pers. Het is de vraag of de media daarmee een bijdrage leveren aan het oplossen van de problemen van de Bijlmerslachtoffers.

\section{Noten}

I S. Wessely, 'Responding to mass psychogenic illness', in: New England Journal of Medicine, 342, 2000, p. 96-100.

2 Eindrapport parlementaire enquête vliegramp Bijlmermeer, Beladen Vlucht, Den Haag 1999, p. 300.

3 A. Boin, M. van Duin, L. Heyse, 'Toxic fear: the management of uncertainty in the wake of the Amsterdam air crash', in: Journal of Hazardous Materials 88, 200I, p. 213-234.

4 Zie: R.E. Kasperson, O. Renn, P. Slovic, H. Brown, J. Emel, R. Goble, J. Kasperson, S. Ratick, 'The Social Amplification of Risk: A Conceptual Framework', in: Risk Analysis 8 (2) 1988. Zie ook: P. Slovic, The perception of risk, London 2000 .

5 J. Petts, T. Horlick-Jones, G. Murdock, Social amplification of risk: The media and the public, Contract research report 329, 200I, p. I.

6 J. Flynn, P. Slovic, H. Kunreuther (eds.), 'Risk, Media and Stigma. Understanding Public challenges to Modern Science and Technology', in: Earthscan 200I, p. 23.

7 P. Vasterman, 'Mediahype', in: Tijdschrift voor Communicatiewetenschap, jrg. 28, najaar 2000. Zie ook: P. Vasterman, Mediahype. Nieuws maken door de opwinding te verslaan, Cahier 20, Faculteit Communicatie en Journalistiek, Utrecht 1999.

8 Zie: E. Singer \& P.M. Endreny, Reporting on Risk: How the Media Portray Accidents, Diseases, Disasters, and Other Hazards, New York 1993.

9 P.M. Sandman, 'Mass Media and Environmental Risks: Seven Principles', in: R. Bate (ed.), What Risk? Science, Politics and Public Health, London 1997.

Io P. Sandman, N.D. Weinstein, W.K. Hallman, 'Communications to Reduce Risk Underestimation and Overestimation', in: Risk Decision and Policy 3 (2), 1998, p. 93-108.

II De diagnose PTss is niet onomstreden en werd pas eind vorige eeuw opgenomen in de Diagnostic and statistical manual of mental disorders (DSM), het classificatiesysteem voor psychopathologie, vooral naar aanleiding van de ervaringen met Vietnam-veteranen. De aandoening toont nogal wat overlap met andere symptomen en aandoeningen, zoals depressie en sombere gevoelens (komen samen voor bij $65 \%$ van de mensen met PTss), angst, somatisatie, alcoholmisbruik en seksuele disfunctie. Bovendien is PTss, net als 'trauma' een inflatoir begrip. Enkele weken na de aanslagen op het wTC in New York verschenen onderzoeksresultaten die aangaven dat op Manhattan, ten zuiden van Canal street, 60.000 gevallen van PTss waren gediagnostiseerd; zowel naar inhoud als naar tijdsverloop een twijfelachtige bevinding.

I2 Zie: P.A. Bertazzi, 'Industrial disasters and epidemiology: A review of recent experiences', in: Scandinavian Journal of Work Environment Health, 15, 1989, p. 85 -100. 
13 S. Wessely, C. Nimnuan, M. Sharpe, 'Functional somatic syndromes: one or many?', in: The Lancet 1999, 354, p. 936-9.

14 A.J. Barsky, J.F. Borus, 'Functional Somatic Syndromes', in: Annals of Internal Medicine, I June 1999, 130, p. 910-921.

Is Wessely, 'Responding to mass psychogenic illness', p. 96-roo. Zie ook: J.K. Razavi, An Outbreak of Chronic Mass Psychogenic Illness at Workplace: A Case of Mental Control Over Physical State Society of Petroleum Engineers Inc., Paper for the Society of Petroleum Engineers Inc. International Conference on Health, Safety and Environment in Oil and Gas Exploration and Production in Kuala Lumpur, 2002.

16 E. Showalter, Hystories: Hysterical Epidemics and Modern Culture, New York 1998, p. 138-139. Zie ook: B. Glassner, Culture of Fear. Why Americans Are Afraid of the Wrong Things. Metaphoric Illness, New York 1999, p. 153-172.

17 C.J. IJzermans, J. van der Zee, Gezondheidsklachten en de vliegramp Bijlmermeer, Amsterdam/Utrecht (AMc/Nivel) 1999. Zie ook: B.P. Gersons, I.V. Carlier, C.J. IJzermans, 'In de spiegel der emoties', in: Maandblad Geestelijke Volksgezondheid, 2000, 55, p. 876-88.

18 IJzermans e.a., Gezondheidsklachten, p. 135 .

I9 P. Vasterman, 'De rampzalige berichtgeving over de parlementaire enquête Bijlmerramp', in: De Journalist, 20 mei 1999.

20 Zie: Gezondheidsraad, Gezondheidsrisico's van blootstelling aan verarmd uranium, Den Haag 200 .

2I IJzermans e.a., Gezondheidsklachten, p. 158.

22 Medisch Onderzoek Vliegramp Bijlmermeer. Deel I: 'Verslag individueel medisch onderzoek', Amsterdam juni 2002 . Het epidemiologisch onderzoek, dat het individueel medisch onderzoek in perspectief moest plaatsen, is voor de groep bewoners inmiddels mislukt, omdat - ondanks veel inspanningen - geen representatieve controlegroep kon worden geformeerd.

23 Mede naar aanleiding van Doemvlucht, de verzwegen geheimen van de Bijlmerramp van ex-Volkskrant journalist Pierre Heijboer, Utrecht 2002. 